Nguyen, T. A. N., Rozsa, Z. (2019). Financial Literacy and Financial Advice Seeking for Retirement

Investment Choice. Journal of Competitiveness, 11(1), 70-83. https://doi.org/10.7441/joc.2019.01.05

\title{
FINANCIAL LITERACY AND FINANCIAL ADVICE SEEKING FOR RETIREMENT INVESTMENT CHOICE
}

\section{- Thi Anb Nbu Nguyen, Zoltan Rozsa}

\begin{abstract}
The research investigates the effects of the degree of financial literacy on financial advice seeking for retirement investment choice as well as assesses the level of financial literacy of Vietnamese employees. An empirical research was conducted by examining 314 individuals who are currently at working stage. This current work also contributes to the present literature by exploring whether the relationship between financial literacy and seeking out advice is a substitute or complementary relationship. The estimation techniques applied in this resaerch are statistics descriptive analysis and two-stage least squares (2SLS) regression. The results of our statistics descriptive analysis indicated that Vietnamese employees have a moderate level of basic and advanced financial literacy. After addressing the endogenous problem by running a two-stage least squares (2SLS) regression, results show that both basic financial knowledge and advanced financial knowledge are positively correlated with financial advice seeking for retirement investment choice. This result also supports the evidence that this relationship may be considered a complementary one. Hence it is recommended that policy makers should concede that along with financial literacy, financial advice ought to be perceived as a complementary mechanism to assist individuals to make informed retirement investment choices.
\end{abstract}

Keywords: financial literacy, financial advice, household finance, investment choice, retirement JEL Classification: D14, G11, G24, J26

Received: December, 2018

1st Revision: January, 2019

Accepted: February, 2019

\section{INTRODUCTION}

Financial advice is becoming an increasingly important topic in many Asian countries. This is especially true in emerging markets where financial markets are being built and developing with complex financial products and services. According to Park \& Estrada (2012), Vietnam in particular is an important emerging financial market in the East and Southeast Asia regions. The launch and quick growth of its stock market, money market and financial instruments, however, may also induce some contrary effects for individual investors. Therefore, it is necessary to assess the needs for and the effects of financial advice, aspects which have not been sufficiently researched. The problem is that individuals normally lack knowledge and comprehensive informa- 
tion about the operation of financial markets. Therefore, acquiring knowledge of the financial system and how financial markets work is extremely important as the fluctuation process of asset prices and inflation could bring a wide range of different outcomes regarding the accumulation of assets and wealth.

According to financial literacy scholars, most people have a limited knowledge of basic financial principles and products (Lusardi \& Mitchell, 2011b; Atkinson \& Messy, 2011). Consequently, they may not be adequately informed to make sound financial decisions. In addition, previous research has demonstrated that financial literacy has important implications about an individual's financial behaviour. For instance, Jappelli \& Padula, (2015a) proved that people with a high level of financial literacy are more likely to prepare for retirement, and high literacy is positively correlated with greater wealth and profitable portfolio allocations in the future. This population also participates in financial markets more often and is better at making sound portfolio choices, which leads to a gradual increase in their wealth (Lusardi \& Mitchell, 2011a, 2011b; Lukášová \& Urbánek, 2014; van Rooij et al., 2011). Therefore, financial literacy plays a vital role in improving this process and it is a key factor in sound financial decision-making (Agarwal et al., 2015; Fernandes et al., 2014).

However, poor financial literacy is not always an excuse for bad financial decisions, as those who lack knowledge and information can seek assistance from qualified consulting services and guidance from experts in financial institutions. As a result, advice from experts can be considered a substitute for financial knowledge in making decisions. To support this idea, it could be argued that financial advice might progress the layman's awareness and it seems to be a valuable source of information for those who are financially illiterate (Fischer \& Gerhardt, 2007). In addition, Haslem (2008) proposes that financial advisors can support or help individuals or investors who are not normally confident to make their own investment decisions.

In contrast to prior studies, the present research explores the links between financial literacy and financial advice seeking in the context of retirement investment choice counselling. Furthermore, previous literature is inexplicit and does not include details of the degree of financial literacy for individuals who lack basic or advanced financial knowledge, and whether there is a difference among these individuals' level of financial literacy which leads them to seek financial advice. Therefore, in this research, financial literacy is measured on different levels appropriate for retirement investment, including self-assessed financial literacy, basic financial knowledge related to basic economic and financial concepts, and advanced financial knowledge related to sophisticated investment concepts such as diversification, asset allocation and risk and return. On the other hand, previous studies have only measured the basic financial knowledge of respondents and focused on investment advisors in general (Kramer, 2016; Calcagno \& Monticone, 2014) or on credit counselling (Disney \& Gathergood, 2013; Disney et al., 2015).

As have found in our literature search, much research has been conducted investigating the interaction between financial literacy and financial advice in the form of retirement investment choice counselling. Some recent studies have in fact studied the relationship between financial literacy and financial counselling services. For instance, Calcagno \& Monticone (2014) showed that investors with a low level of financial literacy are more likely to invest their assets in conservative portfolio choices, and they often have a propensity not to seek counselling or advice 
services. Another research found that households who have achieved a reasonable investment outcome normally possess a high level of financial literacy, or have sought investment counselling (Gaudecker, 2015). In addition to the growth of seeking counselling advice on investments, there has been a rapid increase in credit counselling focusing on home mortgage and consumer credit portfolios. In contrast, Agarwal et al. (2014) showed that mortgage choices are not directly impacted by financial advice. Finally, Disney et al., (2015) think that it is safer in the markets for people with financial illiteracy when they access credit counselling service.

The next section first provides a literature review of studies on financial literacy and financial advice, followed by data and methods, empirical analysis, results and discussion, and conclusions.

\section{THEORETICAL BACKGROUND}

The literature indicates that financial literacy carries important implications about the financial behaviour of the general public. It is believed that those who are more financially savvy are more likely to be active in financial decisions such as saving and investing when they are at working stage in terms of accumulating wealth for their retirement stage (Jappelli \& Padula, 2015a). In agreement with this view, Calcagno \& Monticone (2014) suggest that individual investors should learn about finance to support them to make right financial decisions and optimal investment choices (Capuano \& Ramsay, 2011; Rahman et al., 2018). In addition, Capuano \& Ramsay (2011) argue convincingly that using financial products and services as well as accessing financial markets can be related to the customer's financial literacy. Nevertheless, financial capability depends on the level of education or training in programs related to finance as well as the level of experience along with the sources that are accessed. Along with the development of financial markets with complicated financial products and instruments, financial advice also has a propensity to develop. Advice plays an important role in financial decision processes in terms of information, the correction of a client's cognitive errors, facilitating cognition and overcoming affective issues to make sound investment decisions.

However, a limited number of studies have explored the link between financial literacy and financial advice in the context of retirement investment choice. At present, there are two views on the relationship, i.e. that financial advice is either a substitute for or a complement to financial literacy. Regarding the substitute view, the assumption is that if it is not difficult to find an advisor at low cost, consumers may decide to use advice services as a cheaper substitute than learning from practical experience themselves or by investing in training courses or education programs in financial knowledge (Collins, 2012). This assumption is made regarding those who are more financially savvy and have better understanding of financial products and financial concepts and as a result, might have easier access to financial markets and no demand for counselling services, in which case financial literacy and financial advice can be seen as substitutes. Hung \& Yoong (2010) also support this view in their study, which shows that those with financial illiteracy have a trend towards seeking advice, i.e. a higher barrier exists toward finding out and processing information on financial literacy themselves, so this population prefers to save time and money by seeking advisors (Hackethal et al., 2012; Hung et al., 2009; Hung \& Yoong, 2010). Moreover, 
due to lack of financial literacy, individuals might be less likely to recognize potential conflicts of interest and benefit. Consequently, they take up advisors without hesitation (Hackethal et al., 2012; Inderst et al., 2009).

In contrast to the first view, other researches show empirical evidence that financial literacy and financial advice are complementary. Lusardi \& Mitchell (2011a) single out people who possess basic financial literacy or, in other words, who have knowledge of basic financial concepts related to compound interest, inflation and diversification. This population often tends to access formal sources such as attending seminars and consulting financial experts rather than informal ones such as talking to family, friends and co-workers. In line with this view, van Rooij et al. (2011) and Collins (2012) confirm that people who possess financial literacy are more likely to seek formal sources in newspapers and financial advice than those with a lower financial literacy. Besides understanding basic financial concepts, advanced financial knowledge plays an important role in the recognition of the fact that counselling experts may be necessary to provide valuable information to be put into practice. As such, in this view, counselling advice might be a complement to financial literacy. Moreover, Calcagno \& Monticone (2014) and Collins (2012) contend that the relationship between financial literacy and financial advice is one of complement rather than substitute. In addition, Bucher-Koenen \& Koenen (2015) have found that investors with a high level of financial literacy are more likely to exploit and require advisors to provide better information.

\section{RESEARCH OBJECTIVE AND METHODOLOGY}

\subsection{Research objective}

This research focuses on financial literacy and financial advice seeking relevant to retirement investment choice in the context of emerging markets, especially in the Vietnam market. This research addresses the following two issues:

- Measuring basic and advanced levels of Vietnamese employees' financial literacy

- Evaluating the effects of financial literacy levels on retirement investment advice seeking and whether they have a substitute or complementary relationship.

\subsection{Data}

The survey questionnaire includes four main sections; (1) self-assessed financial knowledge; (2) financial literacy divided into two levels: basic financial knowledge and advanced financial knowledge; (3) financial advice seeking for retirement planning and retirement investment choice counselling; (4) socio-demographic characteristics. The respondents in this research were selected from employees currently working in the private sector and public sector in Ho Chi Minh City and Ha Noi in Vietnam. These are the biggest cities and are also considered to be the main commercial and financial centres of Vietnam, thus organizations and companies in the public sector and the private sector converge in these cities. Particularly, HOSE stock market trading, commercial banks with many branches, mutual funds, and insurance companies are located in these cities. Data collection was conducted in three months at the beginning of 2018 by delivering the questionnaire to each respondent directly and collecting it right after they com- 
plete it. 358 employees participated in this survey, in which 600 questionnaires were distributed. 314 out of 358 questionnaires were retained as valid for the data analysis. 44 questionnaires were eliminated because the respondents did not complete all the questions in the questionnaire or their answers showed bias of extreme values such as answering "Do not know" to all questions in the financial literacy section.

\subsection{Empirical analysis}

Firstly, descriptive statistics were applied to measure basic and advanced financial literacy levels. Then, a multivariate regression analysis was performed to evaluate the effects of financial literacy levels on retirement investment advice seeking. Since retirement investment choice seeking variable is binary, it was estimated by a linear probability model (LPM). Nevertheless, individuals' financial literacy levels could have improved when they accessed the consulting financial advice services and information provided by advisers. For this reason, the LPM estimates could be biased due to reverse causality, indicating that the financial literacy variables have a potential endogeneity problem. To deal with this issue, a two-stage least squares (2SLS) regression was applied to overcome the endogenous problem which causes biased in results. The previous literature in this area has also suggested and demonstrated the endogenous problem of financial literacy, and instrument variables have been proposed to address this issue, i.e. variables which are comprised of the education level of the respondents' parents (van Rooij al., 2011) and of mathematical ability (Jappelli \& Padula, 2013). Moreover, Bernheim et al., (2001) and Lusardi \& Tufano (2015) have used training programs of education in economics and finance at school as an instrument variable of financial literacy in their research. In this research, we follow Lusardi \& Tufano (2015) and Fornero \& Monticone (2011) in applying instrument variables, as this approach was appropriate for our scenario. This means that the instrument variables were made to capture the respondents' financial knowledge before their exposure to retirement investment counselling.

The two-stage least squares (2SLS) regression procedure goes as follows:

$\mathrm{V}_{\mathrm{en}}=\alpha+\beta_{\mathrm{i}} \mathrm{X}_{\mathrm{ex}}+\beta_{\mathrm{i}} \mathrm{X}_{\mathrm{iv}}+\mathrm{u}$

(First stage - Eq.1)

$y=\alpha+\beta_{i} V_{\text {en }}^{*}+\beta_{i} X_{\text {ex }}+\varepsilon$

(Second stage - Eq.2)

Where $V_{\mathrm{en}}$ is the endogenous regressor variable (basic and advanced financial literacy variables); $\mathrm{X}_{\mathrm{ex}}$ is the exogenous regressor variable (self-assessed financial literacy, and socio-demographic variables); $\mathrm{X}_{\mathrm{iv}}$ is the instrument variable (respondents' field of study or participation in any training course related to finance, parents' education level and experience in using financial products or services from financial institutions); $y$ is a dependent variable assessed by whether or not individuals who have made retirement investment choices sought counselling from financial service; $\mathrm{V}^{*}{ }_{\mathrm{en}}$ is the predicted value of $\mathrm{V}_{\mathrm{en}}$ from the first stage; $\beta$ is the vector of the coefficients; $\mathrm{u}$ and $\varepsilon$ are error terms.

\subsection{Measurement variables}

Consulting financial advice on retirement investment choice is considered a dependent variable in this research. This variable is assessed by whether or not individuals who have exercised their 
retirement investment choices sought counselling from financial services. The answer to this question is captured as a dichotomous variable coded 1 when respondents answered "yes" and 0 for those who answered "no".

The independent variables in this research are self-assessed knowledge and financial literacy, both of which were measured in two levels: basic financial knowledge and advanced investment knowledge. The variables were constructed based on prior studies (Lusardi \& Mitchell, 2009; Gallery et al., 2011; van Rooij et al., 2011). Self-assessed financial literacy was constructed on 5-point Likert scales from: " 1 = very low to 5 = very high." A high score shows a higher level of perception regarding the respondent's financial knowledge. Basic financial literacy in this research comprised principles of economic concepts such as interest rate; inflation; time value of money; and money illusion which relate to daily transactions of individuals. Advanced financial literacy requires understanding key concepts related to capital markets such as bonds, stocks, risk diversification, portfolio choice and performance valuation.

In addition to these independent variables, the study measured demographic and socio-economic characteristics such as gender, age, education level, marital status, dependent children and the level of income. This research also included a series of educational/experience variables, i.e. fields of study or participation in any training course related to finance, parents' education level and experience in using financial products or services from financial institutions, which were later used as an instruments variable in the two-stage least squares regression analysis section (Lusardi \& Tufano, 2015 and Fornero \& Monticone, 2011). All of these are constructed as dummy variables.

\section{RESULTS AND DISCUSSION}

\subsection{Data and descriptive statistics}

Tab. 1 - Summary statistics $(\mathrm{N}=314)$. Source: researcher's own based on the sample survey

\begin{tabular}{|l|l|l|l|l|}
\hline & Mean & Std. dev. & Min & Max \\
\hline Financial advice seeking $(1=$ yes $)$ & .596 & .491 & 0 & 1 \\
Financial literacy & & & & \\
Self-assessed financial knowledge score $(1-5 ; 1=$ low $)$ & 2.69 & .997 & 0 & 5 \\
Basic financial knowledge score $(0=$ low, $4=$ high $)$ & 2.37 & 1.029 & 0 & 4 \\
Advanced financial literacy score $(0=$ low, $8=$ high $)$ & 4.15 & 2.095 & 0 & 8 \\
\hline Socio-demographic characteristics & & & & \\
Gender (male $=1)$ & .510 & .5007 & 0 & 1 \\
Age $(1=$ under 25; $2=25-35 ; 3=35-50 ; 4=50-60)$ & 2.271 & .8497 & 1 & 4 \\
$\begin{array}{l}\text { Education level }(1=\text { High school; 2 = Diploma/Bach- } \\
\text { elor's degree; } 3=\text { Postgraduate degree })\end{array}$ & 1.89 & .539 & 1 & 3 \\
\hline
\end{tabular}




\begin{tabular}{|l|l|l|l|l|}
\hline Marital $($ Married $=1)$ & .66 & .476 & 0 & 1 \\
$\begin{array}{l}\text { Number of children }(0=\text { no children, } 3=3 \text { or more } \\
\text { children })\end{array}$ & .89 & .899 & 0 & 3 \\
$\begin{array}{l}\text { Income level }(1=\text { under VND 5 million; 2 = VND 5-9 } \\
\text { million; } 3=\text { VND }>9-15 ; 4=\text { over VND 15 million) }\end{array}$ & 2.72 & .853 & 1 & 4 \\
Home ownership $(1=$ yes $)$
\end{tabular}

Table 1 provides information about the demographic characteristics of respondents currently working in the public sector and private sector in Vietnam, including household members, income and home ownership. The table also reports the descriptive statistics for analysis. The demographic statistics show that just around half of the respondents are male, with the average age distributing to group number two at 26 to 35 -year-old. The majority of respondents have an income of between VND 5-9 million and nearly a half of them own their home (either with or without a mortgage). In addition, 59.6\% of respondents sought recommendations from financial advisors regarding options for retirement investment. The respondents' perceptions of the financial advice services are also rated in terms of trust (mean 2.83), services were too expensive (mean 2.98), and difficulty in finding an advisor (mean 3.29).

\subsection{The measurement of financial literacy}

Based on the prior studies mentioned above, in order to measure and assess financial literacy of respondents in this research, financial literacy was categorized at two levels: basic financial literacy and advanced financial literacy. The first level aimed to evaluate the respondents' understanding of topics ranging from interest compounding, inflation, and time value of money to money illusion. The second level aimed to measure the respondents' level of sophistication regarding financial knowledge, covering topics related to diversification, differences among deposit accounts, bonds and stock, concepts of asset allocation, and concepts of risk and return.

\section{Basic financial literacy}

Tab. 2 - Frequency of responses to basic financial literacy questions $(\mathrm{N}=314)$. Source: researcher's own based on the sample survey

\begin{tabular}{|c|c|c|c|c|c|c|}
\hline \multicolumn{4}{|c|}{$\begin{array}{l}\text { Panel A: Percentage of Correct, Incorrect, "Don't Know" } \\
\text { Responses }\end{array}$} & Correct & \multicolumn{2}{|c|}{ Incorrect/DNK } \\
\hline \multicolumn{3}{|l|}{ Compound interest } & \multicolumn{2}{|c|}{$58.3 \%$} & \multicolumn{2}{|l|}{$41.7 \%$} \\
\hline \multicolumn{3}{|l|}{ Inflation } & \multicolumn{2}{|c|}{$67.5 \%$} & \multicolumn{2}{|l|}{$22.5 \%$} \\
\hline \multicolumn{3}{|l|}{ Time value of money } & \multicolumn{2}{|c|}{$63.1 \%$} & \multicolumn{2}{|l|}{$36.9 \%$} \\
\hline \multicolumn{3}{|l|}{ Money illusion } & \multicolumn{2}{|c|}{$48.4 \%$} & \multicolumn{2}{|l|}{$51.6 \%$} \\
\hline Panel B: Number of Correct Responses & None & 1 & 2 & 3 & All 4 & Mean \\
\hline $\mathrm{N}$ corrects & $3.2 \%$ & $\begin{array}{l}58 \\
18.5 \%\end{array}$ & $29.3 \%$ & $\begin{array}{l}113 \\
36 \%\end{array}$ & $\begin{array}{l}41 \\
13.1 \%\end{array}$ & 2.37 \\
\hline
\end{tabular}


The answers to questions related to basic financial literacy level are reported in Table 2 (panel A). Over half of respondents answered the first three questions correctly. About $60 \%$ gave correct answers to questions on compound interest and time value of money, with the percentage of respondents responding correctly to the question about inflation is over $67 \%$. On the other hand, the proportion of correct answers to the question on money illusion is only $48.4 \%$. The table also shows that just over $13 \%$ of respondents answered all four questions correctly, while the proportion of correct answers to one, two or three questions is much higher. Overall, the average number of correct answers is 2.37 . Therefore, the level of basic financial literacy is considered just over average. This result is similar to that of a commercial bank customer's basic financial knowledge as measured by Nguyen et. al (2017).

\section{Advanced financial literacy}

Tab. 3 - Frequency of responses to advanced financial literacy questions $(\mathrm{N}=314)$. Source: researcher's own based on the sample survey

\begin{tabular}{|l|l|l|}
\hline Panel A: Percentage of Correct, Incorrect / "Don't Know" & Correct & Incorrect/DNK \\
\hline Responses & $60.5 \%$ & $39.5 \%$ \\
Lisky asset & $36.3 \%$ & $63.7 \%$ \\
Volatility & $62.1 \%$ & $37.9 \%$ \\
Diversification & $63.4 \%$ & $36.6 \%$ \\
Asset allocation & $53.8 \%$ & $46.2 \%$ \\
Performance & $38.9 \%$ & $61.1 \%$ \\
Risk rating & $58.0 \%$ & $42.0 \%$ \\
Return rating & $41.7 \%$ & $58.3 \%$ \\
\hline
\end{tabular}

\begin{tabular}{|c|c|c|c|c|c|c|c|c|c|c|}
\hline $\begin{array}{l}\text { Panel B: } \\
\text { Number of } \\
\text { Correct Re- } \\
\text { sponses }\end{array}$ & None & 1 & 2 & 3 & 4 & 5 & 6 & 7 & 8 & 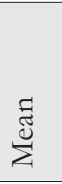 \\
\hline $\mathrm{N}$ corrects & $\begin{array}{l}16 \\
5.1 \%\end{array}$ & $\begin{array}{l}24 \\
7.6 \%\end{array}$ & $\begin{array}{l}28 \\
8.9 \%\end{array}$ & $\begin{array}{l}55 \\
17.5 \%\end{array}$ & $\begin{array}{l}47 \\
15 \%\end{array}$ & $\begin{array}{l}55 \\
17.5 \%\end{array}$ & $\begin{array}{l}44 \\
14 \%\end{array}$ & $\begin{array}{l}30 \\
9.6 \%\end{array}$ & $\begin{array}{l}15 \\
4.8 \%\end{array}$ & 4.15 \\
\hline
\end{tabular}

Table 3, which comprises panels $\mathrm{A}$ and $\mathrm{B}$, is designed to measure advanced financial literacy. While panel A shows the assessment of respondent knowledge related to risks and returns of assets along with the concepts of risk diversification, volatility and performance, panel B shows the advanced level of financial knowledge through the number of correct answers respondents gave to the questions in panel A. It is obvious that the percentage of correct answers to questions related to risk management is relatively higher than that of questions about return concepts. In particular, over $60 \%$ of respondents answered the questions on risky assets, volatility and diversification correctly. Also, more than $53 \%$ and $58 \%$ respectively gave correct answers to questions on asset allocation and risk rating. In contrast, a much lower percentage (over $36 \%$ and 
$38 \%$ ) responded correctly to long-term period return and return rating questions. Panel B shows that a very low proportion of respondents ( $4.8 \%$ ) answered all eight questions correctly. Overall, the average number of correct answers is 4.15 . Thus the level of advanced financial literacy is considered just over average.

\subsection{Regression analysis}

Tab. 4 - Multivariate analysis of retirement investment choice advice seeking. Source: researcher's own based on the sample survey

\begin{tabular}{|l|l|l|l|}
\hline & LPM $(1)$ & LPM $(2)$ & 2SLS (3) \\
\hline Basic financial literacy & & $.1481^{* * *}(.024)$ & $.4822^{* *}(.168)$ \\
Advanced financial literacy & & $.1080^{* * *}(.010)$ & $.0817^{*}(.043)$ \\
Self-assessed financial literacy & & $.0336(.024)$ & $-.0082(.034)$ \\
Male & & & \\
Age (base group: age $<=25)$ & $.0662(.052)$ & $.0149(.042)$ & $-.0119(.055)$ \\
$25<$ age $<=35$ & $.252^{* *}(.083)$ & $.1436^{* *}(.071)$ & $.0816(.091)$ \\
$35<$ age $<=50$ & $.2523 *(.103)$ & $.1123(.088)$ & $.0141(.121)$ \\
$50<$ age $<=60$ & $.2749 *(.132)$ & $.0433(.109)$ & $-.2185(.193)$ \\
Education level (base group: high school) & & & \\
Diploma/Bachelor's degree & $.3976^{* * *}(.065)$ & $.0581(.066)$ & $-.2405(.148)$ \\
Post graduate degree & $.4871 * * *(.094)$ & $.0334(.092)$ & $-.2430(.150)$ \\
Married & $.0909(.082)$ & $.1132 *(.065)$ & $.0728(.086)$ \\
Number of children & $-.0013(.041)$ & $-.0072(.030)$ & $.0046(.039)$ \\
Income \\
(base group: under VND 5 million)
\end{tabular}

Durbin (score) chi2 (2)

Wu-Hausman F (2,296)

First-stage regression (F-test):

- Basic financial literacy

- Advanced financial literacy

$$
\begin{aligned}
& 14.6987(\mathrm{p}=0.0006) \\
& 6.84061 \quad(\mathrm{p}=0.0012) \\
& 20.8 \\
& 24.5
\end{aligned}
$$

Note: Robust standard errors are reported in parentheses; ***P $<0.01, * * \mathrm{P}<0.05, * \mathrm{P}<0.1$ 
Table 4 displays 3 columns: column 1 indicates results of the association between respondent socio-demographic characteristics and retirement investment counselling from a baseline LPM (1) model without effects of the financial literacy factor; column 2 shows results of the relationship between financial literacy and retirement investment choice counselling after adding the financial literacy factor to the model LPM (2); column 3 confirms results when the endogenous problem of financial literacy is addressed by running a 2SLS regression with instrument variables. The dependent variable is a binary variable indicating whether or not individuals sought financial advice for their retirement investment choice, with independent variables expressed comprising self-assessed financial literacy, basic financial literacy, advanced financial literacy, gender, age, education level, marital status, dependent children, home ownership and income level.

Without including the financial literacy factor in the model, the baseline in column 1 displays the coefficient of each age group; the education level is positive and statistically significant to financial advice on retirement investment choice. More particularly, when moving from a diploma or bachelor's degree to postgraduate degree, the probability of retirement investment advice seeking increased from $39 \%$ to $48 \%$ points. These results are partly in line with Hackethal et al. (2012), who found that the age of respondents is positively associated with advice seeking. Recently, Kramer (2016) has indicated that less educated investors have a lower propensity to seek advice.

However, when financial literacy is factored into the model, column 2 shows that basic financial knowledge and advanced financial knowledge are positive and statistically significant to retirement investment counselling at the level of $0.01 \%$. In addition, results regarding retirement investment choice advice seeking varies among studies in terms of demographic characteristics. Compared to those under 25 years old, only people in the group from 26 to 35 tended to seek financial advice regarding retirement investments with a $0.05 \%$ confidence level. In line with this, married people are also more likely to use financial advice service than single people. This finding is also consistent with Hung and Yoong (2010), who show that people with married status have a stronger tendency to seek out financial advice. More recently, however, Hackethal et al. (2012) found the opposite result proving that being married has a negative link with advice seeking.

The two-stage least squares (2SLS) regression shown in column 3 in Table 4 addresses potential reverse causality between retirement investment choice counselling and financial literacy by incorporating instrument variables in the model. As a result, there is a positive and statistically significant relationship between basic financial literacy, advanced financial literacy and retirement investment choice advice seeking at $0.05 \%$ and $0.1 \%$ of confidence level respectively while self-assessed financial knowledge shows no statistically significant relationship with retirement investment advice service. In addition, the result from Wu-Hausman test has rejected the null hypothesis as financial literacy variables are endogeneity variables by $\mathrm{P}$-value $<0.05$. To support these instrument variables which are not weak, F-statistics in the first stage regression of 2SLS are 20.8 for basic financial literacy and 24.5 for advanced financial literacy.

This research confirms some of the findings from previous research on the relationship between financial literacy and financial advice seeking. Most remarkably, those who show a higher level 
of financial literacy are more positive about financial advice seeking, a finding which supports a complementary relationship between financial literacy and financial advice. For instance, van Rooij et al. (2011) discover similar evidence of Dutch in the Netherlands where people with a high level of financial literacy have a tendency to use and access formal sources including financial advice services. In addition, Collins (2012) and Calcagno \& Monticone (2014) also provide evidence that compared to individuals with financial illiteracy, individuals with financial knowledge are more likely to take up financial advice. In line with these findings, a theoretical model of demand for advice of Bucher-Koenen \& Koenen (2015) demonstrates that there is a complementary relationship between sophisticated investors and the quality of advice from advisors. It has been maintained that investors with financial knowledge may understand advice better. In confirmation of this assumption, Georgarakos \& Inderst (2014) have found that a customer's decision to follow the recommendation of an advisor depends mainly on the client's own cognitive financial knowledge.

\section{CONCLUSION}

This paper focuses on the measurement of different levels of financial literacy among Vietnamese employees and assesses the effects of the degree of financial literacy on retirement investment advice seeking. This study also considers whether the relationship between financial literacy and seeking out advice is a substitute or complementary relationship.

Firstly, regarding the level of Vietnamese employee financial literacy, the average level of basic financial literacy and advanced financial literacy was about average, i.e. approximately 2.3 out of 4 , and 4.1 out of 8 respectively, a result which suggests that the overall financial literacy can be considered moderate.

Secondly, the key finding in this study is that $59.6 \%$ of respondents sought advice regarding their retirement investment choices, and those with more basic financial literacy and advanced financial literacy were more likely to seek out advice. This effect is the most noticeable among clients with a greater degree of basic financial literacy. Particularly, by giving one more correct answer to the question on basic financial literacy, participants increased the probability (48 percent points at $0.05 \%$ confident level) that they had sought out advice. In terms of advanced financial literacy, however, this figure is only 8 percentage points at a $0.1 \%$ confidence level. Hence, in line with Calcagno \& Monticone (2014) and Collins (2012), this result confirms that financial literacy and financial advice are of a complementary relationship.

Some final suggestions can be put forward. Firstly, policy makers should acknowledge that along with financial literacy, financial advice needs to be perceived as a complementary mechanism to help individuals make sound retirement investment choices. However, solutions should be instituted in terms of possible intervention mechanisms for clients with a low level of financial knowledge, e.g. inexperienced clients must deal with the challenging problem of potentially biased advice regarding financial services provided by advisors who also function as financial product sales representatives (Inderst \& Ottaviani, 2009; Stoughton et al., 2011). Secondly, more studies into this area should be conducted in terms of emerging markets, particularly in Viet- 
nam. In addition, since this is just the first step, we also plan to expand this research area into the investigation of conflicts of interest among clients and financial intermediaries as well as advisors.

\section{References}

1. Atkinson, A., \& Messy, F. A. (2011). Assessing financial literacy in 12 countries: an OECD/ INFE international pilot exercise. Journal of Pension Economics and Finance, 10 (4), 657-665. https://doi.org/10.1017/S1474747211000539

2. Bernheim, B. D., Garrett, D. M., \& Maki, D. M. (2001). Education and saving: the longterm effects of high school financial curriculum mandates. Journal of Public Economics, 80 (3), 435-465.

3. Bucher-Koenen, T., \& Koenen, J. (2015). Do Seemingly Smarter Consumers Get Better Advice? Max Planck Institute for Social Law and Social Policy Discussion Paper No. 01. http:// dx.doi.org/10.2139/ssrn.2572961

4. Calcagno, R., \& Monticone, C. (2014). Financial literacy and the demand for financial advice. Journal of Banking \& Finance, 50 (1), 363-380.

5. Capuano, A., \& Ramsay, I. (2011). What causes suboptimal financial behaviour? An exploration of financial literacy, social influences and behavioral economics. University of Melbourne Legal Studies Research Paper, No. 540. http://dx.doi.org/10.2139/ssrn.1793502

6. Collins, J. M. (2012). Financial advice: a substitute for financial literacy? Financial Services Review, 21 (4), 307-322. http://dx.doi.org/10.2139/ssrn.2046227

7. Disney, R., Gathergood, J., \& Weber, J. (2015). Credit counseling: a substitute for consumer financial literacy? Journal of Pension Economics and Finance, 14 (4), 466-491. https://doi. org/10.1017/S1474747215000219

8. Fernandes, D., Lynch, J. G., \& Netemeyer, R. (2014). Financial literacy, financial education, and downstream financial behaviors. Management Science, 60(8), 1861-1883. https://doi. org/10.1287/mnsc.2013.1849

9. Fischer, R., \& Gerhardt, R. (2007). Investment mistakes of individual investors and the impact of financial advice. 20th Australian Finance \& Banking Conference 2007 Papers. https:// dx.doi.org/10.2139/ssrn.1009196

10. Fornero, E., \& Monticone, C. (2011). Financial literacy and pension plan participation in Italy. Journal of Pension Economics and Finance, 10 (4), 547-564.

11. Gallery, N., Gallery, G., Brown, K., Furneaux, C., \& Palm, C. (2011). Financial Literacy and Pension Investment Decisions. Financial Accountability \& Management 27 (3), 286-307. https://doi.org/10.1111/j.1468-0408.2011.00526.x

12. Gaudecker, H. M. V. (2015). How Does Household Portfolio Diversification Vary with Financial Literacy and Financial Advice? The Journal of Finance, 70 (2), 489-507. https://doi. org/10.1111/jofi.12231

13. Georgarakos, D., \& Inderst, R. (2014). Financial advice and stock market participation. Available at SSRN: https://ssrn.com/abstract=1641302 http://dx.doi.org/10.2139/ ssrn.1641302 
14. Hackethal, A., Haliassos, M., \& Jappelli, T. (2012). Financial advisors: a case of babysitters? Journal of Banking \& Finance, 36 (2), 509-524. https://doi.org/10.1016/j.jbankfin.2011.08.008

15. Haslem, J. A. (2008). Why Do Mutual Fund Investors Employ Financial Advisors? The Journal of Investing, 17 (04), 91-94. https://ssrn.com/abstract=1319481

16. Hung, A., Parker, A. M., \& Yoong, J. (2009). Defining and Measuring Financial Literacy. RAND Working Paper Series WR-708. http://dx.doi.org/10.2139/ssrn.1498674

17. Hung, A., \& Yoong, J. K. (2010). Asking for Help: Survey and Experimental Evidence on Financial Advice and Behavior Change. RAND Working Paper Series WR-714-1. http:// dx.doi.org/10.2139/ssrn.1532993

18. Inderst, R., \& Ottaviani, M. (2009). Misselling through agents. American Economic Review, 99, 883-908. https://doi.org/10.1257/aer.99.3.883

19. Jappelli, T., \& Padula, M. (2013). Investment in financial literacy and saving decisions. Journal of Banking \& Finance, 37 (8), 2779-2792. https://doi.org/10.1016/ j.jbankfin.2013.03.019

20. Jappelli, T., \& Padula, M. (2015a). Investment in financial literacy, social security, and portfolio choice. Journal of Pension Economics and Finance, 14 (4), 369-411. https://doi. org/10.1017/S1474747214000377

21. Kramer, M. M. (2016). Financial Literacy, Confidence and Financial Advice Seeking. Journal of Economic Behavior \& Organization, 131(A). https://doi.org/10.1016/j.jebo.2016.08.016

22. Lukášová R., \& Urbánek T. (2014). Bank Image Structure: The Relationship to Consumer Behaviour. Journal of Competitiveness, 6 (1), 18-35 https://doi.org/10.7441/joc.2014.01.02

23. Lusardi, A., \& Mitchell, O. S. (2009). How Ordinary Consumers Make Complex Economic Decisions: Financial Literacy and Retirement Readiness. NBER Working Paper No 15350. https://doi.org/10.3386/w15350

24. Lusardi, A., \& Mitchell, O. S. (2011a). Financial literacy and planning: Implications for retirement wellbeing. NBER Working Paper No 17078. https://doi.org/10.3386/w17078

25. Lusardi, A., \& Mitchell, O. S. (2011b). Financial literacy and retirement planning in the United States. Journal of Pension Economics \& Finance, 10 (4), 509-525. https://doi.org/10.1017/ S147474721100045X

26. Lusardi, A., \& Tufano, P. (2015). Debt literacy, financial experiences, and overindebtedness. Journal of Pension Economics \& Finance, 14 (4), 332-368. https://doi.org/10.1017/ S1474747215000232

27. Nguyen, T. A. N, Rozsa, Z., Belas, J., \& Kozubikova, L.(2017). The effects of perceived and actual financial knowledge on regular personal savings: Case of Vietnam. Journal of International Studies, 10 (2), 278-291. https://doi:10.14254/2071-8330.2017/10-2/19

28. Park, D. \& Estrada, G. B. (2012). Developing Asia's pension systems and old-age income support. DBI Working Paper No. 358. http://dx.doi.org/10.2139/ssrn.2052668

29. Rahman, A., Rozsa, Z., \& Cepel, M. (2018). Trade Credit and Bank Finance - Evidence from the Visegrad Group. Journal of Competitiveness, 10 (3), 132-148. 
30. Stoughton, N. M., Wu, Y., \& Zechner, J., (2011). Intermediated investment management. The Journal of Finance, 66(3), 947-980. https://doi.org/10.1111/j.1540-6261.2011.01656.x

31. Sumit, A., Gene, A., Itzhak, B. D., Souphala, C., \& Douglas, D. E. (2014) The effectiveness of mandatory mortgage counseling: can one dissuade borrowers from choosing risky mortgages? NBER Working Paper, No. 19920. https://doi: 10.3386/w19920

32. Sumit, A., Gene, A., Itzhak, B. D., Souphala, C., \& Douglas, D.E. (2015). Financial literacy and financial planning: Evidence from India. Journal of Housing Economics, 27, 4-21. https:// doi.org/10.1016/j.jhe.2015.02.003

33. Van Rooij, M., Lusardi, A., \& Alessie, R. (2011). Financial literacy and stock market participation. Journal of Financial Economics, 101 (2), 449-472.

\section{Contact information}

Thi Anh Nhu Nguyen, Ph.D.

Ho Chi Minh City Open University

Faculty of Finance-Banking

Vietnam

E-mail:nbu.nta@ou.edu.vn

assoc. prof. Zoltan Rozsa, PhD.

Alexander Dubcek. University in Trencin

Faculty of Social and Economic Relations

Slovakia

E-mail: zoltan.rozsa@tnuni.sk. 